\title{
The influence of air-jet and vortex yarn on functionality of woven fabric
}

\section{Influenţa firelor filate cu jet de aer şi vortex asupra funcţionalităţii ţesăturii}

Obiectivul acestui studiu este de a analiza influența structurii firelor filate cu jet de aer şi vortex asupra funcționalității țesăturii. În cadrul studiului, au fost analizate firele cu jet de aer şi vortex comparativ cu firele convenționale filate pe maşina de filat cu inele, din amestecul de 65\% PES / 35\% fibre CO şi finețe 20 tex.

Țesătura cu legătură diagonal T1/3Z a fost realizată din firul filat cu jet de aer, vortex şi filat cu inele în direcția bătăturii, cu două desimi diferite de bătătură (20 şi 30 fire pe cm).

În prima parte a studiului, au fost analizate structura, proprietățile fizice şi mecanice ale firelor filate cu jet de aer, vortex şi filate cu inele, în timp ce în a doua parte a studiului a fost analizată influența firelor utilizate în direcția bătăturii asupra funcționalității țesăturii.

Studiul s-a concentrat în principal pe proprietățile fizice, mecanice, precum şi pe proprietățile de permeabilitate ale țesăturii filate cu jet de aer şi vortex în direcția bătăturii, în comparație cu țesăturile cu fire convenționale filate cu inele în direcția bătăturii, cu compoziție chimică şi finețe a firelor similare.

Rezultatele studiului au evidențiat structura ideală a firului în direcția bătăturii (filate cu jet de aer sau vortex) care aproximează cel mai bine caracteristicile firelor filate cu inele, datorită mecanismului cursor-fus şi a celei mai uniforme structuri, în principal datorită inserării torsiunii reale.

Cuvinte-cheie: fir filat cu jet de aer, fir vortex, fir filat cu inele, țesătură, proprietăți mecanice şi de permeabilitate

\section{The influence of air-jet and vortex yarn on functionality of woven fabric}

The basic intention of the research is to analyse the influence of air-jet and vortex yarn structure on woven fabric functionality. With the research, the air-jet and vortex yarn from the mixture of $65 \%$ PES / $35 \%$ CO fibres and fineness 20 tex were analysed. For comparison, the conventional ring-spun yarn was chosen from the mixture of $65 \%$ PES $/ 35 \%$ CO fibres and fineness 20 tex.

The woven fabric in the twill weave T1/3Z was produced from the air-jet, vortex and ring-spun yarn in the weft direction with two different weft densities (20 and 30 yarns per $\mathrm{cm}$ ).

In the first part of the study, the structure, physical and mechanical properties of the air-jet, vortex and ring-spun yarn were analysed, while in the second part of the research, the influence of used yarn in the weft direction on the functionality of woven fabric was studied.

The research was focused mainly on physical, mechanical properties as well as permeability properties of woven fabric with air-jet and vortex yarn in the weft direction in comparison with woven fabric with conventional ring-spun yarn in the weft direction, with equal chemical composition and fineness of yarn.

The research results was shown which yarn structure in the weft direction of woven fabric (air-jet or vortex) the most closely approximates the characteristics of the ring-spun yarn, which has because of ring-traveller-spindle mechanism ideal and the most even structure, mainly because of the insertion of the true twist.

Keywords: air-jet yarn, vortex yarn, ring-spun yarn, woven fabric, mechanical and permeability properties

\section{INTRODUCTION}

The conventional ring-spinning technology based on the ring-traveller-spindle mechanism, which influences on the true twist insertion of the ring-spun yarn. Mentioned mechanism is almost the same for more than 150 years [1]. The main reason of that is even structure of the ring-spun yarn, wide range of fineness, good mechanical properties that are in the close connection with the number of turns per meter that is the highest for ring-spun yarn in comparison with new spinning techniques [1-3].

In the last few years, many researches were considered with the ring-spun yarn structure in comparison with new spinning techniques such are rotor spinning and air-jet spinning technique $[1,4]$.

Rotor spinning allows much higher levels of productivity than ring-spinning [1]. On the other hand, the second objective has not yet been achieved because of the structure of rotor yarn, which also limits the fineness of count that can be spun. Perhaps the biggest current obstacle facing rotor spinning is the fact that it is limited to coarse and medium yarn counts (16 tex to 120 tex) while ring-spinning excels in the medium to fine counts (finer than $>16$ tex). Yarn manufacture using the air-jet primarily produces fascinated yarns using the false twist principle. Hence, we discuss about the principle of false twisting before going into actual air jet spinning.

The idealized structure of the fascinated yarn consists of parallel fibres held together by wrapper fibres. The wrapper and core fibres are composed of same staple fibre material. Since there is no real twist in the core, this type of yarn structures facilitates high production rates. 
The tenacity of the fascinated yarns spun with air jet depend on the yarn count. The coarser yarns are weaker than the finer yarns for the same fibre type. Contrary to the expectation, yarns produced with finer fibres show lower tenacity compared to the yarns produced with coarser fibres.

The reason for the above observations is that the strength of the fascinated yarns is derived from the amount of wrapper fibres and the intensity of wrapping. The edge fibres are the ones that ultimately are converted into wrapper fibres. The number of edge fibres is limited to the surface of the yarn and are independent of the number of fibres in the core [1-3]. Finally, the vortex spinning is hailed as a revolutionary new technology it can also be viewed as a natural development in the technology of fasciated yarn production. From the earliest inception of fasciated yarns, it was evident that there were limitations, which precluded its wide acceptance [5].

Murata Vortex spinning technology is a modified form of jet spinning which has attracted a lot of attention because of its advantages over ring-spinning, open end and air-jet spinning. It has a high productivity rate, its yarn structure is similar to ring yarn, low hairiness and most important; it is possible to use a wider fibre length range to spin a wider yarn size production rage for $100 \%$ cotton [5-10].

Above-mentioned facts about the ring-spun yarn and especially air-jet and vortex yarn were the basic reason to deal with the influence of air-jet and vortex yarn structure on woven fabric functionality in comparison with conventional ring-spun yarn in the weft direction.

\section{Ring-spinning}

The American Thorp invented the ring-spinning machine in the year 1828. In 1830, another American Jenk, contributed the traveller rotating on the ring. In more than 150 years that have passed since that time, the machine has experienced considerable modification in detail, but the basic concept has remained unchanged.

The ring-spinning machine has been the most widely used form of spinning and it will continue for some more time, because it has unique advantage over new spinning technologies. It is universally applicable, most of the textile fibres can be spun to required fineness. The yarn spun from this machine demonstrates excellent quality features like uniform structure and good strength. It is easy to operate as compared to other spinning machines. It is flexible as regard to quantities in terms of blend and lot sizes. For these reasons, new spinning processes (with the exception of rotor spinning) have difficulty in gaining wide spread acceptance.

Disadvantages of ring-spinning system are low production and that machine generates more heat.

In ring-spinning, the fibre mass of the rove is reduced by a drafting unit. The twist inserted moves upwards and reaches the fibres leaving the drafting unit. The fibres lay around one another in concentric helical path. The normal force encountered by the fibres enhances the adhesive forces between the fibres and prevent fibres from flying or slipping past each other under the tensile strain.

It is the process of attenuating the roving strand until required final yarn count achieved and inserting twist to the fibres by means of a rotating spindle and winding the yarn on a bobbin. These three stages take place simultaneously and continuously. The ring yarn is characterized by high flexibility in the use of the raw material, the yarn count and the yarn character. It possesses a high degree of strength and yarn hairiness [1-3].

\section{Air-jet spinning}

With air-jet spinning a draw frame sliver fed from a can is passed to a drafting arrangement, where it is attenuated by a draft in the range of 100-200. The fibre strand delivered then proceeds to two air jets arranged directly after the drafting arrangement. The second jet is the actual false-twist element.

In air-jet spinning, a sliver is fed to the drafting system; the drafted sliver enters a spinning nozzle. The leading end of the fibres forms the parallel yarn core; the free fibre ends are wound around the yarn core by the air in the spinning nozzle. The air-jet yarn is then wound onto a package.

The air-jet-spun yarn structure consists of core fibres without significant twist and covering fibres with a genuine twist, which ultimately produces the corresponding yarn tenacity. The specific yarn structure results in yarn tenacity between that of a ring-spun yarn and that of a rotor-spun yarn.

The air vortex generated in this jet, with an angular velocity of more than 2 million routes per minute twists the strand as it passes through so that the strand rotates along a screw-thread path in the jet, achieving rotation speeds of about 250,000 routes per minute. The compressed air reaches the speed of sound when entering the central canal of the falsetwist element. Since the axial forces are very low during this rotation, only low tensions arise in the yarn [9-15].

\section{Vortex spinning}

Vortex spinning technology was introduced by Murata Machinery Ltd. Japan in 1997. This technology is best explained as a development of air-jet spinning, making use of air jets for yarn twisting. The main features of Murata vortex spinning (MVS) are ability to produce yarn at $400 \mathrm{~m} / \mathrm{min}$, which is almost 20 times greater than ring-spinning frame production and low maintenance costs, a fully automated piecing system and elimination of roving frame. The yarn and the fabric properties of MVS yarn are claimed by the manufacturer to be comparable to those of ring-spun yarn.

Vortex yarn has a two-part structure: a core surrounded by wrapper fibres. The number of wrapper fibres compared to the fibre core is higher compared to the air jet spinning. During yarn formation, the leading ends of the fibres are directed towards the yarn core and the trailing ends wrap around the core 
fibres. Such a structure provides the necessary fibre orientation and, at the same time, the required yarn strength.

One problem with the vortex system is significant fibre loss during the yarn formation. This is related to the problem of variations in yarn quality, which are not detectable by conventional evenness testers and sometimes only identified by weak points in the finished fabric. The path followed by the fibre in the currents created by the air jets play a crucial role in yarn quality. Most structural defects are caused by the deflection of fibres in the air jet from their ideal path [4-9].

\section{EXPERIMENTAL}

\section{Materials}

The basic intention of the research is to analyse the influence of air-jet and vortex yarn on woven fabric functionality. With the research, the air-jet and vortex yarn from the mixture of $65 \% \mathrm{PES} / 35 \%$ CO fibres and fineness 20 tex were analysed. The air-jet yarn had the false twist while the vortex yarn had 695 twists/m. For comparison, the conventional ring-spun yarn was chosen from the mixture of $65 \%$ PES/35 \% $\mathrm{CO}$ fibres and fineness 20 tex and 789 twists $/ \mathrm{m}$.

For the intention of our research, six woven fabrics were designed and produced on the weaving machine Minifaber (Italy) with Jacquard mechanism TIS (France). The woven fabrics were produced in the twill weave $T 1 / 3 Z$ from the air-jet (A20, A30), vortex (V20, V30) and ring-spun yarns (R20, R30) in the weft direction with two different weft densities (20 and 30 yarns per $\mathrm{cm}$ ).

Table 1 presents the SEM images of air-jet, vortex and ring-spun yarn in the weft direction of fabric. Ring-spun yarn is produced using true twist insertion from the outer to inner layer and has the most even structure (table 1: Ring-spun yarn - longitudinal and cross-sectional view). On the other side the air-jet yarn is produced using false twist insertions caused by air vortex generated in two jets, with an angular velocity of more than 2 million routes per minute.

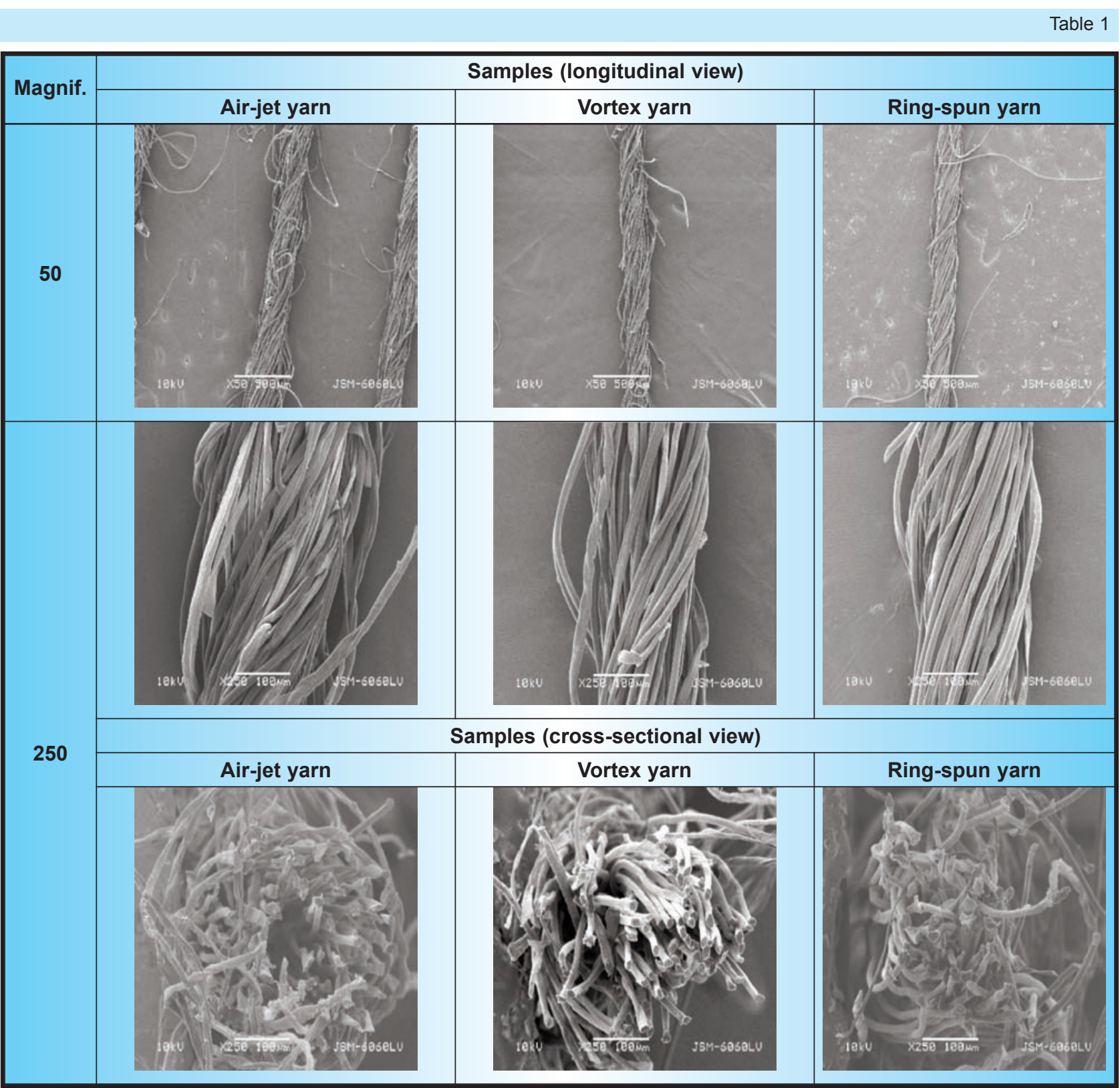


Because of that the air-jet-spun yarn structure consists of core fibres without significant twist and covering fibres with a genuine twist (table 1: Air-jet yarn longitudinal view and cross-sectional view). On the contrary, the vortex yarn is produced using true twist insertion. Vortex yarn has a two-part structure: a core surrounded by wrapper fibres (table 1). The number of wrapper fibres compared to the fibre core is higher compared to the air-jet spinning.

Table 2 presents the microscope images of woven fabrics analysed with the magnifications $10 \mathrm{x}, 20 \mathrm{x}$ and $30 \mathrm{x}$.

Table 2

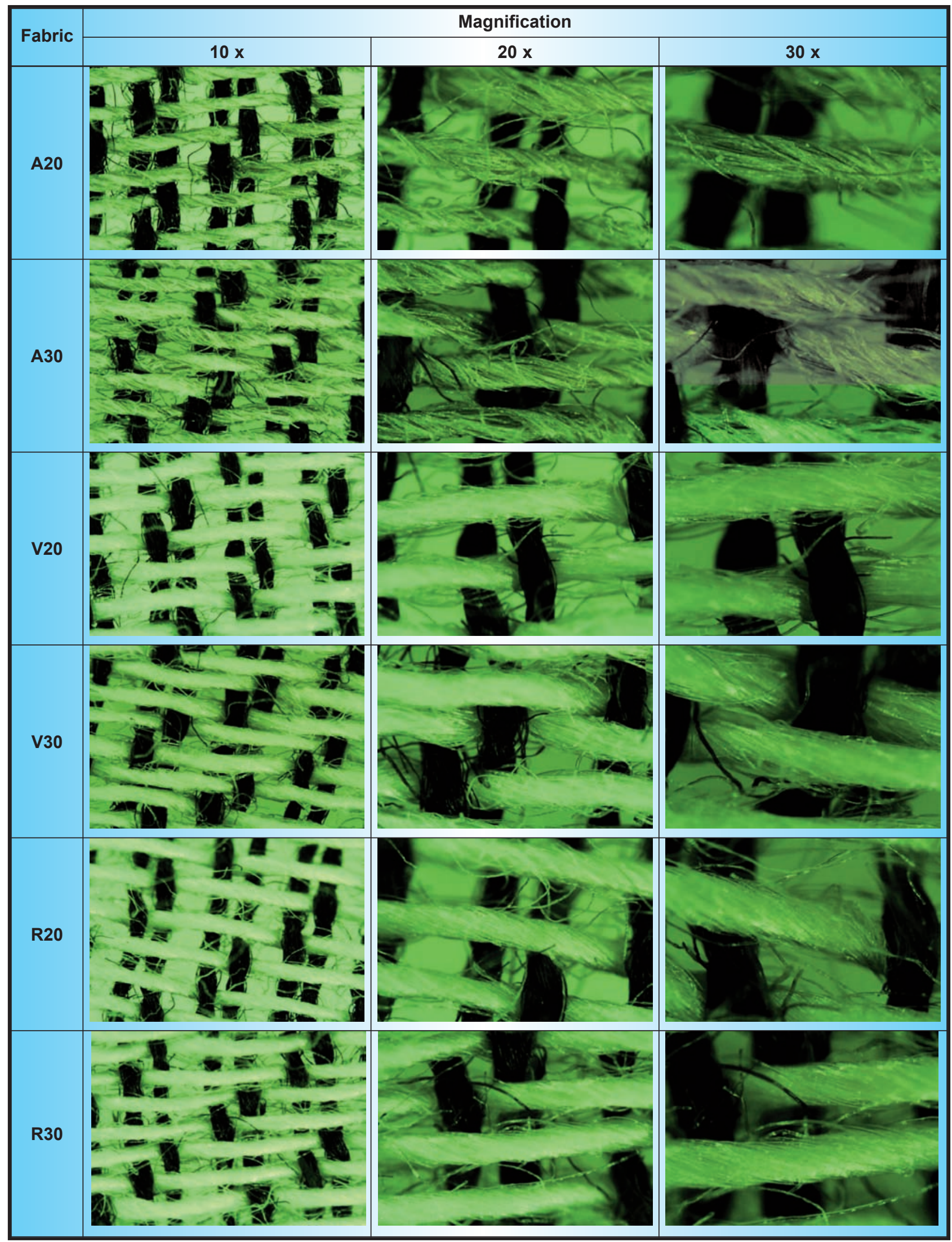




\begin{tabular}{|c|c|c|c|c|c|c|}
\hline Sample & $\begin{array}{c}\text { Yarn in the } \\
\text { weft direction }\end{array}$ & $\begin{array}{l}\text { Mass, M } \\
\left(\mathrm{g} / \mathrm{m}^{2}\right)\end{array}$ & $\begin{array}{l}\text { Thickness, } \mathrm{h} \\
\text { (mm) }\end{array}$ & $\begin{array}{l}\text { Warp density } g_{0} \\
\quad(\text { yarns } / \mathrm{cm})\end{array}$ & $\begin{array}{l}\text { Weft density, } g_{v} \\
\quad(y a n s / c m)\end{array}$ & $\begin{array}{l}\text { Diameter of } \\
\text { yarn, } d(\mu \mathrm{m})\end{array}$ \\
\hline A20 & Air-jet & 78.140 & 0.364 & 20.6 & 21.2 & 260.000 \\
\hline A30 & Air-jet & 90.040 & 0.383 & 21.6 & 30 & 214.333 \\
\hline V20 & Vortex & 75.740 & 0.379 & 20.8 & 22.8 & 288.333 \\
\hline V30 & Vortex & 91.760 & 0.385 & 21.4 & 31 & 234.333 \\
\hline R20 & Ring-spun & 78.860 & 0.363 & 21 & 21.8 & 235.000 \\
\hline R30 & Ring-spun & 94.420 & 0.373 & 20.6 & 29.6 & 200.333 \\
\hline
\end{tabular}

The fabric mark $\mathrm{A} 20$ and $\mathrm{A} 30$ presented woven fabric with air-jet yarn in the weft direction with the weft density 20 yarns per $\mathrm{cm}$ (A20) and 30 yarns per $\mathrm{cm}$ (A30), while fabrics with vortex yarn in the weft direction was signed as V20 and V30 with two different weft densities (20 and 30 yarns per $\mathrm{cm}$ ). The fabric with ring-spun yarn in the weft was signed as R20 and R30 with two different weft densities (table 2).

The ring-spun yarn from $100 \%$ CO was used in the warp direction. The density in warp direction was the same for all fabrics, 20 yarns per $\mathrm{cm}$. Linear density of ring-spun yarn in warp direction was 16 tex, with $537 \mathrm{twists} / \mathrm{m}$. All yarns in the warp and weft directions had $Z$ twist direction.

Table 3 presents the structural properties of fabrics analysed

\section{METHODS}

The first part of the research deals with mechanical properties of air-jet, vortex and ring-spun yarn, which were chosen for the research. According to mentioned above, the breaking force and elongation of yarns were measured according to ISO 2062. For each sample of yarn, the twenty-five measurements were done and breaking stress of yarn was calculated. Finally, from the stress/extension curve of each yarn, the stress and extension in the yield point and elasticity modulus were calculated using SigmaPlot 9 programme.

Further, the breaking force and breaking elongation of woven fabric were carried according to standard SIST EN ISO 13934 (Textiles - Tensile properties of fabrics-Part 1, 2013) on dynamometer INSTRON 5567 [16]. Five measurements were done for each sample. Finally, the breaking stress was calculated. The analysis of the stress/extension curve was done also using SigmaPlot 9 programme to achieve some basic viscoelastic factors, such are the stress and extension in the yield point and elasticity modulus.

In the second part of the research, some functional properties of woven fabrics analysed were carried on. Air permeability of fabrics analysed was carried on according to ISO 9237 on the five different places of each fabric [17]. Finally, the air permeability in $1 / \mathrm{m}^{2} \cdot \mathrm{h}$ was measured on the Mesdan Lab apparatus (figure 1). The measuring area was $20 \mathrm{~cm}^{2}$.

Water vapour permeability was measured according to ASTME96:E96M [18]. Two measurements were

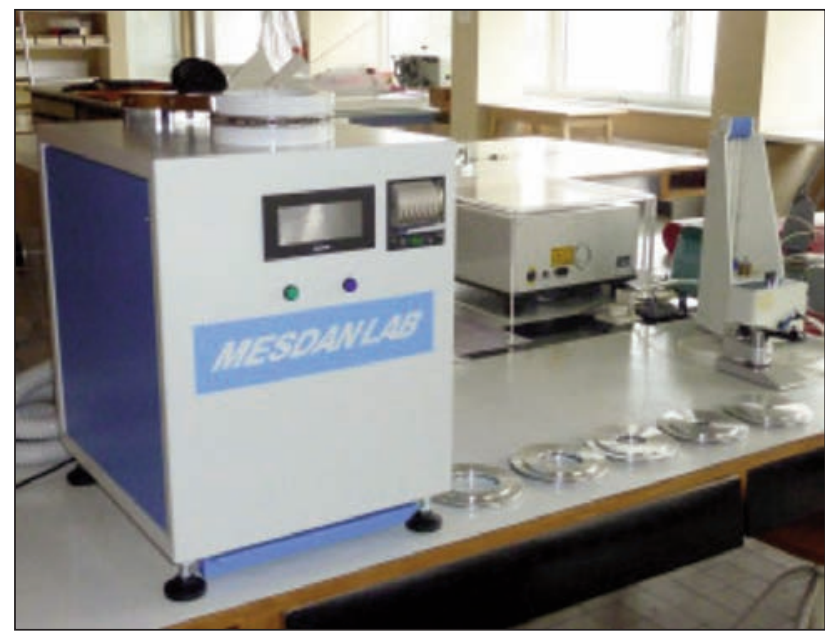

Fig. 1. Mesdan Lab apparatus

done of each sample and finally the water vapour permeability was calculated, WVT, Equation (1).

$$
W V T=\frac{m_{24}-m_{0}}{s \cdot t}\left(\mathrm{~g} / \mathrm{m}^{2} \cdot \mathrm{t}\right)
$$

$m_{24}$ is mass of the sample on the cup of water after 24 hours $(\mathrm{g})$;

$m_{0}$ - mass of the sample on the cup of water at the beginning (g);

$S$ - area of measuring $\left(S=7,065 \mathrm{~cm}^{2}\right)$;

$t$ - measuring time 24 hours (h).

The experimental results (breaking stress and extension, stress and extension in the yield point, elasticity modulus, air permeability of fabrics and water vapour permeability of fabrics analysed were statistically processed by the multifactor ANOVA using StatisticXL programme. All analyses were carried out at $95 \%$ confidence level[19].

\section{RESULTS AND DISCUSSION}

\section{Breaking stress and extension of yarns analysed}

Table 4 presents the results of breaking stress and extension of air-jet, vortex and ring-spun yarn.

The results of breaking stress and extension of yarns analysed have shown that the highest breaking stress and extension was noticed for ring-spun yarn. The results of breaking stress and extension of vortex yarn present the middle value between ring-spun and air-jet yarn. The reason of the highest breaking 


\begin{tabular}{|l|c|c|c|c|c|c|}
\hline \multicolumn{1}{|c|}{ Yarn } & $\begin{array}{c}\text { Breaking } \\
\text { stress, } \sigma_{\text {br }} \\
(\mathbf{c N / t e x )}\end{array}$ & $\begin{array}{c}\text { Standard } \\
\text { deviation, s } \\
\text { (cN/tex) }\end{array}$ & $\begin{array}{c}\text { Coefficient of } \\
\text { variation, CV } \\
(\mathbf{\%})\end{array}$ & $\begin{array}{c}\text { Breaking } \\
\text { extension, } \boldsymbol{\varepsilon} \\
(\%)\end{array}$ & $\begin{array}{c}\text { Standard } \\
\text { deviation, s } \\
(\%)\end{array}$ & $\begin{array}{c}\text { Coefficient of } \\
\text { variation, CV } \\
(\%)\end{array}$ \\
\hline Air-jet & 11.064 & 35.809 & 16.446 & 5.367 & 1.024 & 19.081 \\
\hline Vortex & 16.622 & 38.065 & 11.691 & 7.553 & 0.726 & 9.612 \\
\hline Ring-spun & 24.522 & 35.291 & 7.214 & 10.633 & 0.571 & 5.372 \\
\hline
\end{tabular}

stress and extension of ring-spun yarn lies in the structure of ring-spun yarn, which has the highest number of twist (789 twists/m). The number of twists has an important impact on mechanical properties such are breaking stress and breaking extension. The lowest breaking stress and extension expressed air-jet yarn, which is produced with the false twisting the sheath fibres around the core fibres. Only $5 \%$ of the sheath fibres are wound around the core. That is the main reason for the lowest breaking stress and extension.

\section{Stress and extension in the yield point and elasticity modulus of yarns analysed}

Table 5 presents the results of the stress and extension in the yield point and elasticity modulus of yarns analysed.

The results of the stress and extension in the yield point are shown that the highest yield point (the stress and extension in the yield point) has ring-spun yarn, which means the wider region of elastic deformation. The reason lies in the structure of the ringspun yarn, which expresses the highest twist.

The results of the elasticity modulus, which present the resistance of fabric under loading in the elastic region to the limit of elastic deformation (the yield point), show that ring-spun yarn expresses the highest elasticity modulus in comparison with air-jet and vortex yarn. Ring-spun yarn has also the highest breaking stress and extension, means that the stress/extension curve of ring-spun yarn has steeper slope in the field of elastic deformations than the curve of air-jet or vortex yarn. The lowest elasticity modulus has air-jet yarn, mainly because of false twist insertion during production of air-jet yarn, which results in the lower percentage (only 5-percents) of the sheath fibres, which are wound around the core than with vortex yarn. The number of wrapped fibres of vortex yarn compared to the fibre core is higher in comparison to the air-jet spinning process. During yarn formation, the leading ends of the fibres are

\begin{tabular}{|l|c|c|c|}
\hline Yarn & $\begin{array}{c}\text { Stress in the } \\
\text { yield point, } \\
\sigma_{\mathbf{y}} \text { (cN/tex) }\end{array}$ & $\begin{array}{c}\text { Extension } \\
\text { in the yield } \\
\text { point, } \varepsilon_{\mathbf{y}}(\%)\end{array}$ & $\begin{array}{c}\text { Elasticity } \\
\text { modulus, } \mathrm{E}_{\mathbf{0}} \\
(\mathbf{c N} / \text { tex) }\end{array}$ \\
\hline Air-jet & 0.036 & 1.333 & 0.036 \\
\hline Vortex & 0.043 & 1.500 & 0.037 \\
\hline Ring-spun & 0.044 & 1.500 & 0.042 \\
\hline
\end{tabular}

directed towards the yarn core and the trailing ends wrap around the core fibres. Such a structure provides the necessary fibre orientation and at the same time, the required yarn strength which influences on the higher elasticity modulus than elasticity modulus of air-jet yarn.

\section{Breaking stress and extension of fabrics analysed}

Table 6 presents the results of breaking stress and extension of fabrics analysed.

From the results of breaking stress and extension of woven fabrics, it can be found that the fabrics with the ring-spun yarn in the weft direction express the highest breaking stress and breaking extension in the weft direction (36.685 N/mm ${ }^{2}$ and $\left.21.00 \%\right)$. The breaking stress in the weft direction is the highest with fabrics, which incorporate ring-spun yarn (R20 and R30), means for the fabrics with weft density 20 yarns/cm and 30 yarns $/ \mathrm{cm}$. The reason lies in the structure of the ring-spun yarn, which expresses the highest twist and influences on the highest breaking stress and extension in the weft direction.

The lowest breaking stress and breaking extension is measured with fabrics A20 and A30 that incorporate air-jet yarn in the weft direction $\left(19.637 \mathrm{~N} / \mathrm{mm}^{2}\right.$ and $14.222 \%$ ).

The reason of the lowest breaking stress and extension lies in the false twist insertion during production process of air-jet yarn, which results in the lower percentage (only 5-percents) of the sheath fibres which are wound around the core than with vortex yarn.

The results of breaking stress and breaking extension of fabrics V20 and V30 that incorporate vortex yarn are between the values of fabrics with air-jet yarn in the weft (A20, A30) and ring-spun yarn in the weft direction (R20, R30).

Table 6

\begin{tabular}{|c|c|c|c|c|}
\hline \multirow{2}{*}{ Fabric } & \multicolumn{2}{|c|}{$\begin{array}{c}\text { Breaking stress, } \\
\sigma_{\text {br }}\left(\mathbf{N} / \mathbf{m m}^{2}\right)\end{array}$} & \multicolumn{2}{c|}{$\begin{array}{c}\text { Breaking extension, } \\
\varepsilon_{\text {br }}(\%)\end{array}$} \\
\cline { 2 - 5 } & Warp & Weft & Warp & Weft \\
\hline A20 & 13.895 & 14.192 & 9.333 & 10.61110 \\
\hline A30 & 13.249 & 19.187 & 9.944 & 13.111 \\
\hline V20 & 12.266 & 19.637 & 8.388 & 14.222 \\
\hline V30 & 12.036 & 27.517 & 8.666 & 15.778 \\
\hline R20 & 12.779 & 25.881 & 9.722 & 19.388 \\
\hline R30 & 13.784 & 36.685 & 9.944 & 21.000 \\
\hline
\end{tabular}


From the results of breaking stress and extension of woven fabrics, it can be also found that the structure of yarn (air-jet, vortex and ring-spun yarn) has an important impact in the weft direction. In the warp direction, the differences among the values of breaking stress and extension are minor and move between $12.036 \mathrm{~N} / \mathrm{mm}^{2}$ and $13.895 \mathrm{~N} / \mathrm{mm}^{2}$ and $8.388 \%$ and $9.944 \%$.

From the results it is also seen that with the increasing weft density (from 20 to 30 yarns $/ \mathrm{cm}$ ), the breaking stress and extension increase. Mentioned results are expected.

The statistical analysis ANOVA shows a statistically important influence of the used yarn structure in the weft direction on the breaking stress and breaking extension value, especially in the weft direction.

\section{Stress and extension in the yield point and elasticity modulus of fabrics analysed}

Tables 7 and 8 present the results of stress and extension in the yield point and elasticity modulus in the warp and weft direction.

The results of the elastic limit (the stress and extension in the yield point) of woven fabrics in the warp direction show the highest value of the stress and extension in the yield point with fabric A20, which incorporate air-jet yarn. That results shown that fabric with air-jet yarn in the weft has higher stress and extension in the yield point and lower elasticity modulus in the warp direction in comparison with fabrics which incorporate vortex and ring-spun yarn in the weft direction. On the other side the elasticity modulus of fabrics R20 and R30 is the highest. Means that fabrics R20 and R30 with ring-spun yarn in the weft

Table 7

\begin{tabular}{|c|c|c|c|}
\hline Fabric & $\begin{array}{c}\text { Stress in the } \\
\text { yield point, } \\
\sigma_{\mathbf{y}}\left(\mathbf{N} / \mathbf{m m}^{2}\right)\end{array}$ & $\begin{array}{c}\text { Extension in } \\
\text { the yield } \\
\text { point, } \boldsymbol{\varepsilon}_{\mathbf{y}} \mathbf{( \% )}\end{array}$ & $\begin{array}{c}\text { Elasticity } \\
\text { modulus, } \mathbf{E}_{\mathbf{0}} \\
\left(\mathbf{N} / \mathbf{m m}^{2}\right)\end{array}$ \\
\hline A20 & 0.725 & 3.333 & 0.116 \\
\hline A30 & 0.590 & 3.333 & 0.134 \\
\hline V20 & 0.276 & 1.833 & 0.126 \\
\hline V30 & 0.492 & 2.667 & 0.140 \\
\hline R20 & 0.164 & 2.055 & 0.208 \\
\hline R30 & 0.622 & 3.000 & 0.172 \\
\hline
\end{tabular}

Table 8

\begin{tabular}{|c|c|c|c|}
\hline Fabric & $\begin{array}{c}\text { Stress in the } \\
\text { yield point, } \\
\sigma_{\mathbf{y}}\left(\mathbf{N} / \mathbf{m m}^{2}\right)\end{array}$ & $\begin{array}{c}\text { Extension in } \\
\text { the yield } \\
\text { point, } \boldsymbol{\varepsilon}_{\mathbf{y}}(\mathbf{\%})\end{array}$ & $\begin{array}{c}\text { Elasticity } \\
\text { modulus, } \mathbf{E}_{\mathbf{0}} \\
\left(\mathbf{N} / \mathbf{m m}^{2}\right)\end{array}$ \\
\hline A20 & 0.577 & 2.000 & 0.992 \\
\hline A30 & 1.033 & 3.167 & 0.280 \\
\hline V20 & 0.805 & 2.33 & 0.345 \\
\hline V30 & 1.548 & 3.333 & 0.326 \\
\hline R20 & 0.890 & 2.833 & 0.220 \\
\hline R30 & 1.598 & 3.833 & 0.215 \\
\hline
\end{tabular}

direction are less deformable in the elastic region on the stress/extension curve.

The results of the stress and extension in the yield point in the weft direction show that the highest yield point have fabrics R20 and R30 with ring-spun yarn in the weft direction. From the results, it is seen that fabrics V20 and V30 that have vortex yarn in the weft direction also show very high values of the stress and extension in the yield point. Means that fabrics with ring-spun and vortex yarn express higher yield point and higher limit of elastic deformations than fabrics with air-jet yarn in the weft direction.

The structure of vortex yarn is very similar to ringspun yarn, which results in similar values of the stress and extension in the yield point of fabrics R20 and R30 with ring-spun yarn in the weft and with V20 and V30 with vortex yarn in the weft direction.

The results of elasticity modulus show that the highest value of elasticity modulus has fabrics V20 and V30 with vortex yarn in the weft. The reason of that lies in the two-component structure of vortex yarn (core and the sheath fibres).

The results also show that with increasing weft density (from 20 to 30 yarns $/ \mathrm{cm}$ ), the yield point and elasticity modulus also increases. Mentioned results are expected.

The statistical analysis ANOVA shows a statistically important influence of the structure of yarn in the weft direction on the stress and extension in the yield point value and elasticity modulus especially in the weft direction

\section{Air permeability of fabrics analysed}

Table 9 presents the results of air permeability of fabrics analysed.

The results of air permeability of fabrics show that the highest air permeability was measured with fabrics R20 and R30 with ring-spun yarn in the weft direction. Reason lies in the so-called ideal structure of ring-spun yarn and the highest twist of ring-spun yarn, which influences on the lower number of short projecting fibres that ensures the highest air permeability for the both weft densities, 20 and 30 yarns $/ \mathrm{cm}$ of fabrics (R20 and R30). Fabrics A20 and V20 which incorporate air-jet and vortex yarn in the weft direction have similar value of air permeability (19.94 and $19.87 \mathrm{l} / \mathrm{min} \cdot \mathrm{cm}^{2}$ ). Fabrics A30 and V30 (weft density: 30 yarns $/ \mathrm{cm}$ ) also express similar values of air

\begin{tabular}{|c|c|}
\hline Fabric & $\begin{array}{l}\text { Air permeability, } \\
\left.\text { Q (I/ min } \cdot \mathrm{cm}^{2}\right)\end{array}$ \\
\hline A20 & 19.94 \\
\hline A30 & 13.33 \\
\hline V20 & 19.87 \\
\hline V30 & 12.77 \\
\hline R20 & 21.58 \\
\hline R30 & 14.53 \\
\hline
\end{tabular}


permeability, A30 (13.33 l/min $\left.\cdot \mathrm{cm}^{2}\right)$ and V30 (12.77 $\mathrm{I} / \mathrm{min} \cdot \mathrm{cm}^{2}$ ).

Air-jet and vortex yarn have two-component structure from the core and wrapped fibres (the sheath), which influence on the projecting fibres increase on the yarn surface and finally on the woven fabric surface. The projecting fibres on the fabric surface influence on the air permeability decrease.

The results of air permeability also show that with increasing density, air permeability of fabric decreases. The statistical analysis ANOVA shows a statistically important influence of the structure of yarn in the weft direction on air permeability of fabrics analysed.

\section{Water vapour permeability}

Table 10 presents the results of water vapour permeability of fabrics analysed.

The highest water vapour permeability was measured with fabric R20, which incorporates ring-spun yarn in the weft direction. Ring-spun yarn of fabric R20 has because of higher twist, lower number of projecting fibres on the fabric surface, which influences on higher water vapour permeability (189.137 $\mathrm{g} / \mathrm{m}^{2} \mathrm{~h}$ ). Contrarily, the fabrics V30 (vortex yarn in the weft) and A30 (air-jet yarn in the weft) which have, because of two-component structure (core and sheath fibres), higher number of projecting fibres on the fabric surface which prevent water vapour permeability, that is in that case lower $\left(136.53 \mathrm{~g} / \mathrm{m}^{2} \mathrm{~h}\right.$ for fabric V30 and $121.137 \mathrm{~g} / \mathrm{m}^{2} \mathrm{~h}$ for fabric A30).

The results show that with increasing density, the water vapour permeability of fabrics analysed decreases.

The lowest water vapour permeability with fabrics with warp density 30 yarns $/ \mathrm{cm}$ was measured with fabric R30 that incorporates ring-spun yarn in the weft direction mainly because of the structure of ringspun yarn in the woven fabric. With the density increase (from 20 to 30 yarns $/ \mathrm{cm}$ ), the structure of woven fabric in the case of the ring-spun yarn is less opened than in the case of fabric A30 (air-jet yarn in the weft) and V30 (vortex yarn in the weft) with the same weft density.

The results of water vapour permeability also show that fabrics V20 and V30 with vortex yarn in the weft show higher values than fabrics $\mathrm{A} 20$ and $\mathrm{A} 30$ with airjet yarn in the weft. Reason lies in the structure of vortex yarn, which is two-component, but the percentage of wrapped fibres around the core is higher

Table 10

\begin{tabular}{|c|c|}
\hline Fabric & $\begin{array}{c}\text { Water vapour permeability } \\
\text { WVT }\left(\mathbf{g} / \mathbf{m}^{\mathbf{2}} \mathbf{h}\right)\end{array}$ \\
\hline A20 & 138.417 \\
\hline A30 & 121.137 \\
\hline V20 & 179.406 \\
\hline V30 & 136.530 \\
\hline R20 & 189.137 \\
\hline R30 & 113.116 \\
\hline
\end{tabular}

than in the case of air-jet yarn in the weft (fabrics A20 and A30). That means less projecting fibres on the surface of fabrics A20 and A30 which influence on the lower water vapour permeability.

The statistical analysis ANOVA shows a statistically important influence of the structure of yarn in the weft direction on water vapour permeability of fabrics analysed.

\section{CONCLUSIONS}

Based on the presented research of the influence of air-jet and vortex yarn structure on woven fabric functionality, the following conclusions could be drawn:

- Vortex yarn, which has similar structure to ringspun yarn (the true twist insertion in the both cases) expresses the middle values of breaking stress and extension which move betwen the breaking stress and extension of air-jet yarn and ring-spun yarn.

- The limit of elastic deformation (the yield point) of vortex yarn is very close to the ring-spun yarn yield point value, while the elasticity modulus value lies between the elasticity modulus of air-jet yarn (false twisting) and ring-spun yarn (true twisting).

- Fabrics with ring-spun yarn in the weft direction have in general the highest breaking point and the yield point level, especially in the weft direction.

- Fabrics with vortex yarn in the weft direction have in general higher breaking point and the yield point than fabrics with ring-spun yarn in the weft direction.

- On the other hand fabrics with vortex yarn in the weft express the highest elasticity modulus, mainly because of two-component structure of vortex yarn (the core and sheath fibres) with higher value of the wound sheath fibres than with air-jet yarn (only $5 \%$ of wound sheath fibres).

- Fabrics with vortex and air-jet yarn in the weft express similar air permeability, while fabrics with ring-spun yarn express the highest air permeability, mainly because of lower number of projecting fibres on the fabric surface of that kind of fabrics.

- On the other hand the water vapour permeability of fabrics with vortex yarn in the weft express higher value than fabrics with air-jet yarn in the weft. Fabrics with ring-spun yarn in the weft express the highest water vapour permeability.

Based on the facts presented above, it could be concluded that the incorporation of vortex yarn in the weft direction improves the breaking stress and extension and the yield point level (the limit of elastic deformations) in comparison with fabric with air-jet yarn in the weft direction and consequently the region of elastic deformations (more than $50 \%$ ).

The vortex yarn in the weft direction improves the elasticity modulus level. The elasticity modulus presents the resistance of a fabric under loading in the elastic region under the stress/extension curve. Means, the woven fabrics which incorporate vortex yarn in the weft are less deformable and express a wider region of elastic deformations. The research shows that the highest breaking stress and extension 
and also the yield point, expresses fabric with the ring-spun yarn in the weft direction. While the breaking stress and extension and the yield point of fabric with vortex yarn in the weft lie between the values of ring-spun yarn and air-jet yarn. That shows that the structure of vortex yarn is close to the ring-spun yarn with so-called ideal structure.

Further the projecting fibres of air-jet and vortex yarn influence on the air permeability and water vapour permeability decrease in comparison with ring-spun yarn which has ideal structure and is produced using true twist insertion. The structure of vortex yarn pre- sents the combination of the structure of ring-spun yarn (wound sheath fibres) and air-jet yarn (two component structure with lower value of wound sheath fibres - only 5-percents). That is the main reason of permeability properties of vortex yarn with measured permeability values which are between the values of ring-spun and air-jet yarn.

The research confirmed that woven fabrics with vortex yarn in weft significantly improve the mechanical and permeability properties of fabrics in comparison with woven fabrics which incorporate air-jet yarn in the weft.

\section{BIBLIOGRAPHY}

[1] Lawrence, C.A. Fundamentals of spun yarn technology, In: London: CRC Press, 2003, 552 p.

[2] Subhash, B.W., Barrie, F. Engineering fundamentals of ring spinning/twisting, over-end unwinding and two-for-one twisting in textile processes, In: Lancaster: DEStech Publications, 2015, 186 p.

[3] Tasnim N.S., Someshwar S.B. Engineering techniques of ring spinning, In: New Delhi: WPI Publishing, 2015,223 p.

[4] Lawrence, C.A. Advances in yarn spinning technology, In: Cambridge: The Textile Institute, 2010, 431 p.

[5] Erdumlu, N., Ozipek, B., Oxenham, W. Vortex spinning technology, In: Textile Progress, vol. 44, no. 3-4, 2012.

[6] Han, C., Xue, W., Cheng, L., Yao, J. Comparative analysis of traditional jet vortex spinning and self-twist jet vortex spinning on yarn mechanism and yarn properties, In: Textile Research Journal, vol. 86, no. 16, 2016, pp. 1750-1758.

[7] Li, M., Yu, C., Shang, S. Effect of vortex tube structure on yarn quality in vortex spinning machine, In: Fibers and Polymers, vol. 15, no. 8, 2014, pp. 1786-1791.

[8] Pei, Z., Yu, S. Investigation on the dynamic behavior of the fiber in the vortex spinning nozzle and effects of some nozzle structure parameters, In: Journal of Engineered Fibers and Fabrics, vol. 6, no. 2, 2011, pp. 16-29.

[9] Zhong, Y.H., Ma, J.H., Xing, M.J. Fiber configuration of air jet vortex spinning yarns, In: Advanced Materials Research, vol. 834-836, 2014, pp. 1784-1788.

[10] Basu, A. Progress in air-jet spinning, In: Textile Progress, vol. 29, no. 3, 1999, pp. 1-38.

[11] Basal, G., Oxenham, W. Vortex spun yarn vs. Air-jet spun yarn, In: Autex Research Journal, vol. 3, no. 3, 2003, pp. 96-101.

[12] Ahmed, S., Syduzzaman, M., Mahmed, S., Ashique, S.M. Comparative study on ring, rotor and Air-jet spun yarn, In: European Scientific Journal, vol.11, no.3, 2015, pp. 411-424.

[13] Zeng, Y.C., Wan, Y.Q., Yu, C.W., He, J.H. Controlling the air vortex twist in air-jet spinning, In: Textile Research Journal, vol. 75, no. 2, 2005, pp. 175-177.

[14] Abdal, H.A., Hamdy, A.S., Khalil, K.A. Lim, L.H. A novel simple one-step air jet spinning approach for deposition of poly(vinyl acetate)/hydroxyapatite composite nanofibers on Ti implants, In: Material Science Engineering, vol. 49, 2015.

[15] Witczak, D., Golanski, J. Air flow in the air-jet false-twist spinning chamber, In: Fibres \& Textiles In Eastern Europe, vol. 15 , no. 3, 2007, pp. 45-48.

[16] Textiles - Tensile properties of fabrics - Part 1: Determination of maximum force and elongation at maximum force using the strip method, In: ISO 13934-1:2013, 12 p.

[17] Textiles - Determination of the permeability of fabrics to air, In: ISO 9037: 2011.

[18] Standard Test Methods for Water Vapor Transmission of Materials", In: ASTM E96/E96M: 2016,14 p.

[19] Vik, P. Regression, ANOVA, and the General Linear Model: A statistics primer, In: Sage Publication, 2014,344 p.

\section{Authors: \\ ŠAJN GORJANC DUNJA \\ GLAŽAR DOMINIKA}

University of Ljubljana, Faculty of Natural Sciences and Engineering, Department of Textiles,

Graphic Arts and Design, Ljubljana, Slovenia, Snezniska 5, SI-1000 Ljubljana

\section{Corresponding author:}

ŠAJN GORJANC DUNJA

e-mail: dunja.sajn@ntf.uni-lj.si 